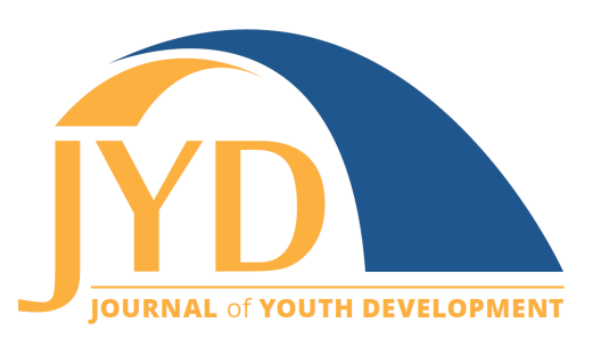

http://jyd.pitt.edu/ | Vol. 15 Issue 6 DOI 10.5195/jyd.2020.1056 | ISSN 2325-4017 (online)

\title{
A Roadmap for Youth Thriving: A Commentary on the Arnold and Gagnon Vision for Positive Youth Development
}

\author{
Richard M. Lerner \\ Institute for Applied Research in Youth Development, Tufts University \\ richard.lerner@tufts.edu
}

\begin{abstract}
Youth development researchers and practitioners have the common goal of understanding and enhancing the positive development of all young people. The work of Professors Mary Arnold and Ryan Gagnon on the 4-H Thriving Model provides a creative and richly theoretically and empirically informed vision for promoting positive youth development (PYD) through integrating youth development research and practice. Their vision is an exemplar of how theoretically predicated and cutting-edge developmental science and the enactment of youth programs can be mutually informative. Drawing on the theory, research, and ideas for program design encompassed within the Science of Learning and Development (SoLD) Alliance, which applies developmental scholarship that integrates research from multiple disciplines and underscores the malleability, agency, and specificity of mutually influential coactions between youth and their contexts, Professors Arnold and Gagnon illustrate the features of research $\Leftrightarrow$ practice integration that must be enacted for innovative progress in programs aimed at enhancing youth thriving. The compelling roadmap for promoting PYD through the integrations framed by the 4-H Thriving Model will advance youth development practice, developmental science theory and research and, most important, the lives of the diverse young people of our nation.
\end{abstract}

Key words: positive youth development; Science of Learning and Development (SoLD), research-practice integration, 4-H Thriving Model

The work of Professors Mary Arnold and Ryan Gagnon on the 4- $\mathrm{H}$ Thriving Model continues to give inspiring voice to the importance of creating a bridge between developmental science theory, methodology, and research and program practices in both $4-\mathrm{H}$ and in the youth development sector more generally. That is, in the parlance of dynamic, relational developmental systems-based theories (Overton, 2015), the scholarship of Professors Arnold and Gagnon is a major contribution to a developmental science $\Leftrightarrow$ practice relation. Their work in

(cc) EY New articles in this journal are licensed under a Creative Commons Attribution 4.0 License. This journal is published by the University Library System, University of Pittsburgh and is cosponsored by the University of Pittsburgh Press. The Journal of Youth Development is the official peer-reviewed publication of the National Association of Extension 4-H Youth Development Professionals and the National AfterSchool Association. 


\section{A Roadmap for Youth Thriving}

the study of positive youth development (PYD) has been, and continues to be, an exemplar of how cutting-edge developmental science and the enactment of youth programs across the 4-H system can be mutually informative, and the scholarship they have produced regarding the 4-H Thriving Model has deservedly attracted attention across the 4-H system and, as well, across the youth development field more generally.

The present article is an invited commentary on Professors Arnold and Gagnon's (2020) most recent presentation of the 4-H Thriving Model, which is an exemplar of their important and timely scholarship. It is both a pleasure and an honor to have been asked to provide my thoughts about the work of these colleagues, especially because their article is marked by the inclusion of several sections (e.g., "Further Research: What Works for Whom under What Conditions?"; p. 14) that provide a compelling roadmap for instantiating a major emphasis in their scholarship, an emphasis that is also a foundational feature of contemporary developmental science, that is research $\Leftrightarrow$ practice integration in the service of enhancing thriving among all young people. Their discussion of the research and development work of the Science of Learning and Development (SoLD) Alliance (e.g., Cantor et al., 2019; DarlingHammond et al., 2020; Osher et al., 2020), which applied developmental scholarship that integrates information from several disciplines (e.g., biology, medicine, psychology, education, sociology, law, and public policy), well illustrates the features of the road that Professors Arnold and Gagnon are illuminating for progress in enhancing youth thriving.

\section{The Theory and Research Approach of SoLD}

Professors Arnold and Gagnon explain that

Program theory provides an explanatory account of how a program works, with whom, and under what conditions (Astbury \& Leeuw, 2010), and identifies the causal processes through which program success takes place (Pawson, 2013). (p. 14)

and that

The 4-H Thriving Model represents the first attempt to articulate the 4-H program's theory of change to elucidate the processes through which 4-H achieves its outcomes (Chen, 2004). (p. 14)

They then go on to note (p. 16) that 


\section{A Roadmap for Youth Thriving}

Recent consensus research highlights that youth have varying learning and developmental needs, influenced in large part by their contexts, brain malleability, and presence of buffering relationships (Bonnie \& Backes, 2019; Cantor et al., 2019). The result of this research is a new emphasis on the science of learning and development, which is leading advances in contemporary developmental science and will surely have a key influence on youth development practice in the years to come (Lerner, Geldhof, \& Bowers, 2019). Consistent with program design principles identified in the science of learning and development, the need to elucidate the processes of youth development is key to ensuring that 4-H and all PYD programs generate intended outcomes for youth [emphasis added].

This statement reflects an exciting vision for an innovative addition contemplated by Professors Arnold and Gagnon for the 4-H Thriving Model, one that I strongly endorse.

As explained in two articles by leaders of the SoLD Alliance and of its R \& D work more specifically (Cantor et al., 2019; Osher et al., 2020), and summarized also in an issue of the Journal of Youth Development (Lerner, 2019), the theoretical frame for this work is dynamic, relational developmental systems theories (Overton, 2015) as, for instance, exemplified by Urie Bronfenbrenner (e.g., 2005; Bronfenbrenner \& Morris, 2006), Margaret Beale Spencer (2006; Spencer, et al., 2015), William Damon $(2008,2015)$ and by Kurt Fischer and his colleagues (e.g., Fischer \& Bidell, 2006; Mascolo \& Bidell, 2020; Mascolo \& Fischer, 2015; Rose, 2016). These theories of human development specify that the process of development involves mutually influential relations between a specific individual and the specific features of his or her context, represented usually in this literature as individual $\Leftrightarrow$ context relations. When these relations are mutually beneficial, a basis for PYD, or thriving, occurs. When these relations involve a person in the individual's context, as for instance may occur between a specific youth and his or her specific adult program leader, then "youth $\Leftrightarrow$ practitioner relationship" may be used to represent this connection.

In any case, the point well made by Professors Arnold and Gagnon is that the 4- $\mathrm{H}$ Thriving Model must evolve to take into consideration the specificity of these youth $\Leftrightarrow$ practitioner relationships. This point is a cornerstone of contemporary developmental science, both within the work of SoLD and across the field of developmental science more generally. Presented in the writing of Society for Research in Child Development Past-President Marc Bornstein as the specificity principle (e.g., Bornstein, 1995, 2006, 2017, 2019), this idea supports the above- 


\section{A Roadmap for Youth Thriving}

quoted point of Professors Arnold and Gagnon, that useful program theory-and the 4-H Thriving Model in particular-should specify the specific ways in which a program works, with which specific youth, and under what specific program and broader ecological conditions. Accordingly, and again pointing to the already-quoted point made by Professors Arnold and Gagnon, the vision-that the 4-H Thriving Model should be used by practitioners, researchers, and program evaluators to learn what specific program actions are effective, for what specific youth, under what specific contextual conditions-will enable the work of 4-H program practitioners to contribute to promoting thriving for each 4-H youth, no matter the gender, race, ethnicity, religion, socioeconomic status, sexual orientation, ability status, or geographic location of the young person. At the same time, the model will enable building a stronger bridge between cutting-edge developmental science researchers and practitioners-which has been a defining goal of the 4-H Thriving Model.

I focus on this defining feature of the conceptual frame used by Professors Arnold and Gagnon because I think their vision for the evolution of the 4- $\mathrm{H}$ Thriving Model to occur in relation to the work of SoLD is of utmost importance for both developmental science per se and for the translation of developmental science into specific practices in 4-H programs. That is, some of the findings of that colleagues and I are contributing to the SoLD research and development work are providing data in support of importance of the specificity principle for several features of the 4-H Thriving Model. A useful example of this connection is the measurement of Executive Functioning (Yu et al., 2020; Yu et al., under review).

With funding from the Chan Zuckerberg Initiative (CZI), SoLD research and development researchers have selected some constructs within the Building Blocks for Learning (BBFL) framework (Stafford-Brizard, 2016) that are integral for positive academic and life development. We have studied the child-specific development of these constructs among elementary-, middle-, and high-school students across the country. Using sources such as the NIH Toolbox and reviews by McClelland, Geldhof, and their colleagues $(2015,2018)$, person-specific measures of three constructs were developed: (a) executive function (EF), which involved the components of cognitive flexibility, behavioral inhibition, and working memory; (b) intentional self-regulation (ISR), involving goal selection, goal optimization, and compensation; and (c) relationship skills (RS), including empathic concern, perspective taking, and social competence. Our goal for all measure development was to minimize participants' burden and continue to engage students when measures are administered several times a week. These goals would contribute to valid assessment and avoid measurement bias. Our intention was to use these 


\section{A Roadmap for Youth Thriving}

measures to assess (a) whether meaningful individually-specific changes occurred during the 2019-2020 school year and (b) if averages across participants were good representations of youth-specific pathways.

Perhaps needless to say at this writing, the COVID-19 pandemic and the closing of schools interrupted our plans to study each child in a classroom across at least 50 occasions of measurement. Nevertheless, although the pandemic disrupted our study, we were able to obtain more than 30 repeated measures with a sufficient number of youth to assess if they showed individually-specific changes in our measures and, as well, if averages across participants were good representations of youth-specific pathways. Although within each classroom students were presented with a standard curriculum, no student showed EF changes in the same way (Yu et al., 2020; Yu et al., under review). For instance, for each of the three measures of $\mathrm{EF}$, each student had a specific pathway, even in the face of the same contextual (classroom) experiences, that is, the same pedagogical program. Statistical analyses indicated that each student's pathway varied in meaningful, explicable ways (for example, changes in EF could be explained in part by changes in attention levels). In addition, the average pathway for EF across the students in each classroom did not adequately represent the pathway of any specific student. Simply, the average was not an accurate depiction of development for any student.

The SoLD child-specific (idiographic) data comport completely with the argument made by Professors Arnold and Gagnon regarding the need for future research pertinent to the evolution of the 4-H Thriving Model to be framed by tests of the specificity principle! They are, therefore, presenting a vision that aligns with the cutting-edge developmental science scholarship ongoing by SoLD researchers as well as by researchers also focused on the specificity of individual $\Leftrightarrow$ context relations (e.g., pediatrician Jack Shonkoff and his colleagues (2017) at the Center for the Developing Child at Harvard University).

Furthermore, the alignment between their vision for the future development of the 4- $\mathrm{H}$ Thriving Model and developmental science research also has profound implications for translating research into $4-\mathrm{H}$ practice, especially because of the SoLD evidence that the same (classroom) curriculum is not linked to the same development of children or adolescents experiencing this curriculum. This point enables me to turn to some of the other facets of Professors Arnold's and Gagnon's article that I believe are impacted by their insights regarding future research pertinent to the 4-H Thriving Model. 


\section{A Roadmap for Youth Thriving}

\section{The Borden, Perkins, and Hawkey (2014) Commentary}

Professors Arnold and Gagnon quite appropriately open their article by summarizing the 2014 commentary presented by Lynne Borden, Daniel Perkins ${ }^{1}$, and Kyle Hawkey in the Journal of Extension. There are a lot of ideas in the commentary with which I strongly agree. For instance, I agree with their points that it is important to increase professional development efforts for $4-\mathrm{H}$ staff and volunteers, particularly in the area of program quality, and that it is equally important to develop better program evaluation processes that assess content outcomes and the quality of the program that leads to those outcomes. However, I think that Borden, Perkins, and Hawley are, at best, imprecise, and at worst, wrong, in recommending that there needs to be standard 4-H program implementation. In fact, and in the context of cutting-edge developmental science, as represented by the above-noted SoLD theory and research that Professors Arnold and Gagnon explain, any attempt to pursue, or (even worse) impose, standard implementation would be doomed to fail in the face of the specificity of youth and context and the relations between each specific youth and the context, that is, specific individual $\Leftrightarrow$ context relations.

In fact, and in disagreement with the assertion of Pawson (2013), the history of science supports the idea that variation in, and not uniformity of, implementation of a model best enables the illumination of the process through which successful outcomes are achieved. To use but one of many examples, from the 1920s through the 1970s (a half-century span) there were literally thousands of studies of "conditioning and learning" conducted in hundreds of different labs in different universities (e.g., Kimble, 1961; Reese \& Lipsitt, 1970). These studies varied in manners important for my present point. The studies had specific procedures for implementing their research, and each publication emanating from these sites described the specific ways of conducting (implementing) the research-all of which were presented in the specific Method section of the publication. However, despite this enormous diversity of implementation, general principles of the learning process were verified time and time again in this research. That is, the "laws" of response acquisition, extinction, generalization, etc. were identified in this research, despite the variation in how a specific study was implemented. In fact, variation in implementation was appropriately recognized as a strength in this literature because the same principles (latent processes of learning) kept on being verified. Thus,

\footnotetext{
${ }^{1}$ In the interest of full disclosure, Daniel Perkins was my student from his undergraduate days through his Ph.D. and Lynne Borden was trained by one of my Pennsylvania State University Ph.D. graduates, Jasna Jovanovic.
} 


\section{A Roadmap for Youth Thriving}

specificity does not interfere with research precision or with being able to specify process, that is, the actions in specific settings that were linked to specific outcomes among specific participants. Such specification of process is the story of science.

Accordingly, creating a standard program may at first glance sound good as a principle, but both the contemporary and needed future developmental science research to which Professors Arnold and Gagnon correctly point and, as well, reports from youth program practitioners, both in the United States and internationally, converge in stating that the "quest" to create a standard program across place and time is ill-conceived and not possible to implement in any society, for any program, that has been used in the youth development field. As Bornstein's specificity principle notes, theory and research in developmental science indicate that human development varies across time and place (e.g., see the work of Glen Elder, which dates back to 1974), and healthy and positive development depends on adapting programs to fit the specific times, places, and people engaged in programs-a point emphasized by Professors Arnold and Gagnon. As such, a standard approach to implementing programming will end up being inadequate for specific individuals, developing in specific places, at specific times in life and history.

Professors Arnold and Gagnon quite appropriately point (see p. 2) to the ideas of Roth and Brooks-Gunn (2016), that youth development programs need to pay increasing attention to developing better definitions and measurement for youth development, making advances in the design and evaluation of programs, focusing on programs as a context for youth development, and integrating both prevention and promotion practices.

As do Professors Arnold and Gagnon, I believe that Roth and Brooks-Gunn are completely correct. I also think that Professors Arnold and Gagnon are correct in the belief embodied in the 4-H Thriving Model that participation in a high-quality youth development program helps youth thrive (again see p. 2). Therefore, because there is abundant evidence that high-quality youth development programs are a context promoting positive youth development (see for instance, the review by Vandell et al., 2015), and because programs vary across sites within time and within sites across time, any standard approach to context cannot succeed. The specificity of person, context, and time must then be a fundamental aspect of program design, implementation, and evaluation. 


\section{A Roadmap for Youth Thriving}

As pointed out by Professors Arnold and Gagnon and by members of the SoLD R \& D group, everything we know about human development in general, and youth development in particular, is that specificity of individual, time, and place must be taken into account for every young person to thrive in any specific program context. Programs that are designed to address the average (or nomothetic) young person (a person that does not actually exist; Rose, 2016) will not serve the needs of a specific youth-as documented in the above-noted SoLD research about EF, RS, and ISR (Yu et al., 2020; Yu et al., under review) and, as well, as explained in the work of SoLD Alliance member Todd Rose, in his book, The End of Average (2016). As Professors Rose and Arnold and Gagnon would agree, there is no such thing as the average youth!

In short, for youth programs to develop in the direction envisioned by Professors Arnold and Gagnon in their specification for future research needed to advance the 4-H Thriving Model, and for youth programs to align with the research and development work of the SoLD group, attention to the dynamic relations among a specific youth, a specific program, and a specific time in both life and history have to be integratively understood. This integration in the service of specificity does not gainsay the importance of $4-\mathrm{H}$ practitioners using a general model, such as the 4-H Thriving Model, to frame their work. However, it may require that the $4-\mathrm{H}$ youth development specialist approach the principles of such a model with an understanding of the difference between a principle and its implementation in practice. In the terminology used in the research of the SoLD colleagues and in the tests of the 4- $\mathrm{H}$ Thriving model discussed by Professors Arnold and Gagnon, the difference between a guiding principle and a feature of program practice is essentially a difference between latent and manifest variables.

\section{The Need for a National Model for 4-H Youth Development}

Professors Arnold and Gagnon make a compelling call for the importance of a national model of PYD for use in the programs of $4-\mathrm{H}$. They also note that there are several approaches or frameworks about the meaning of PYD that exist, and I agree with them that there are "some with little or no science to support them" (p. 4). I appreciate, as well, their frank call for the use of theory-predicated and methodologically rigorous developmental science research (such as they note is associated with the SoLD research and development group) in the building and enactment of the national model.

In addition, and perhaps somewhat surprisingly, I agree that the research of Lerner and Lerner on the Five Cs model of PYD does not involve a specific translation into specific practices to be 


\section{A Roadmap for Youth Thriving}

enacted by specific practitioners, working in specific communities, and presenting specific programs, to enhance specific outcomes of the program for each specific child in the program. Professors Arnold and Gagnon note also quite correctly that there are several excellent, theoryand research-based models of PYD other than the Lerner and Lerner model. A superb example is the model of youth purpose developed by Stanford University developmental scientist William Damon and his colleagues and students (e.g., Damon, 2008). Damon's PYD model has been used successfully by Cornell University researchers with 4-H youth in New York State (e.g., Burrow et al. ${ }^{2}$, 2018). As with the Lerner and Lerner Five Cs model, the Damon purpose model also does not involve a specific translation into the several facets of specificity involved in the specificity principle.

Of course, one can assert that such translation was not the purpose of the research or the skill set of the authors of this research. Although true, such a statement misses what I regard as the key point in regard to all of the PYD models that have been formulated across the past 2 decades (see the review by Lerner et al., 2015). As noted at the outset of the present article, these models are all instances of dynamic, relational developmental systems theories of human development. Although all of these models may differ in regard to what they measure at the observable (manifest variable) level-the Five Cs, purpose, individual or ecological assets, youth sparks, or components of the BBFL framework-all models are identical in regard to the latent variables they believe are involved in creating the manifestation (the measured variables) associated with any particular model of PYD. At the latent variable level, all of the models share a common conceptual frame, that is dynamic, individual $\Leftrightarrow$ context relations between a specific youth and a specific context constitute the fundamental process of human development; therefore, all models focus on the individual specificity of the adolescent, context, and temporal conditions, no matter how they are measured at the manifest level.

Therefore, Professors Arnold and Gagnon are correct in noting that research about the Five Cs models "lacked practical specificity on how to translate the research into effective youth development practice" (p. 5). However, this point must be qualified to add that there can be no specific instructions about how to use this model—or any model of the manifest variables involved in PYD—for formulating specific instructions applicable to all 4-H programs. Indeed, my point here is underscored by the specificity principle-based vision that Professors Arnold and

\footnotetext{
2 (Burrow, Agans, \& Rainone, 2018,) Again, in the service of full disclosure, Jennifer Agans, who is now at Penn State, was my Ph.D. student and worked as an RA on a project studying the development of entrepreneurial purpose conducted by William Damon and me and, as well, Anthony Burrow was trained by one of my Penn State Ph.D. graduates, Jonathan Tubman.
} 


\section{A Roadmap for Youth Thriving}

Gagnon present for the future, in their section on, "Further Research: What Works for Whom Under What Conditions?" (pp. 14-15).

In fact, following this vision of Professors Arnold and Gagnon, attempts to provide one set of manifest instructions to practitioners for how to enhance thriving among each specific youth in their specific community and specific program would constitute, at best, conceptual confusion. The implication of Professors Arnold and Gagnon's vision for future research about the 4-H Thriving Model and for its alignment with the SoLD research leads to the point that each instantiation of a 4-H program must not follow the same procedures for establishing a positive context for youth development. Each program has to adjust its approach on the manifest variable level in order to make certain that the program is designed and delivered in a way that meets the specific needs of the specific youth involved in it at a specific time in the life span of the young person and, as well, at the specific time the youth and the program exist in history. Youth programming, after the COVID-19 pandemic subsides, will be very different than youth programming before the pandemic, perhaps especially for young people whose parents and communities were most at risk for contracting the virus.

In other words, I believe that there should be no model of the specific and uniform, nationallyinvariant way in which key principles of PYD should be translated into program actions. Although the principles (the latent variables associated with best practice in youth development) should be of concern to all practitioners, how these latent constructs are translated into manifest actions must vary to fit the specifics of each youth participant and each time and place in which the program is enacted. That is, competent practitioners must be sensitive to racial, ethnic, and cultural diversity and, therefore, to the possibility that, for specific youth, different principles (latent variables) may apply. Spencer and Spencer (2014) have made this point in a compelling manner in their critique of the Lerner and Lerner 4-H Study of PYD.

Any model of PYD must, then, differentiate between, on the one hand, the specific (manifest variable) actions needed by specific practitioners for specific youth-a specificity that will necessarily vary in relation to the diversity of youth, practitioners, programs, and communitiesand, on the other hand, invariant adherence, on a latent level, to the theory- and researchbased (but latent variable) principles of human development identified in the research of developmental scientists, such as those involved in the SoLD research work. 


\section{A Roadmap for Youth Thriving}

\section{Conclusions}

I believe that the vision for the further development of the 4- $\mathrm{H}$ Thriving model that has been formulated by Professors Arnold and Gagnon is a major asset in creating enthusiasm and energy around such a major reformulation of the research-to-practice translation for which they call. Indeed, I think that their vision can help align U.S.-based PYD work translating research into practice through use of the specificity principle with corresponding international efforts (e.g., Bornstein, et al., in press). In the international arena, USAID, UNICEF, sponsorship organizations such as Compassion International, and the World Brank are engaging in precisely the type of translation I have described in, literally, thousands of specific communities in the majority world.

In sum, Professors Arnold and Gagnon's timely and important article suggests that at least one superordinate goal of their work is to call for a new approach to creating greater alignment between research and practice-to build a bridge wherein travelers move in both directions. The world is moving in accordance with this bidirectional relationship-as illustrated at this moment in history between scientists addressing the pandemic and front-line practitioners addressing the health needs of people who have the virus or who are at risk for contracting it (e.g., Bornstein 2020; Ettekal \& Agans 2020).

Professors Arnold and Gagnon have presented a vision for increasing the flow of this two-way traffic. I see their vision as building a bridge wherein there is increasingly greater alignment of research $\Leftrightarrow$ practice relations with dynamic, relational developmental systems models, with the specificity principle, and with the increasingly common research practice of differentiating between a structural (latent variable) model and a measurement (manifest variable) model.

In pursuing their vision, I anticipate that Professors Arnold and Gagnon will create in the 4-H Thriving Model a specification of how latent constructs of individual $\Leftrightarrow$ context relations can be transformed into youth- and program-specific coactions that create positive change in specific children. Such work will illuminate how a practitioner may elicit and maintain engagement for each specific youth in his or her program, how the specific requirements for engaging each youth may be identified and monitored across time, and what specific steps will be taken if engagement fades. Such specification, predicated on the future research envisioned by Professors Arnold and Gagnon, will advance the profound and enduring contributions that 4-H programs have made and will continue to make to the thriving of every young person in its programs. 
Journal of Youth Development | http://jyd.pitt.edu/ | Vol. 15 Issue 6 DOI 10.5195/jyd.2020.1056

\section{A Roadmap for Youth Thriving}

\section{References}

Arnold , M. E., \& Gagnon, R. J. (2020). Positive youth development theory in practice: An Update on the 4-H Thriving Model. Journal of Youth Development, 15(6), 1-23. https://doi.org/10.5195/jyd.2020.954

Astbury, B., \& Leeuw, F. L. (2010). Unpacking black boxes: Mechanisms and theory building in evaluation. American Journal of Evaluation, 31(3), 363-381. https://doi.org/10.1177/1098214010371972

Bonnie, R. J., \& Backes, E. P. (Eds.). (2019). The promise of adolescence: Realizing Opportunity for all Youth. National Academies Press.

Borden, L. M., Perkins, D. F., \& Hawkey, K. (2014). 4-H Youth Development: The past, the present, and the future. Journal of Extension, 52(4). https://joe.org/joe/2014august/comm1.php

Bornstein, M. H. (1995). Parenting infants. In M. H. Bornstein (Ed.), Handbook of parenting (Vol. 1, pp. 3-39). Erlbaum.

Bornstein, M. H. (2006). Parenting science and practice. In K. A. Renninger \& I. E. Sigel (Eds.), Child psychology in practice. Volume 4 of the Handbook of child psychology (pp. 893-949) (6 $6^{\text {th }}$ ed.). Editors-in-Chief: W. Damon \& R. M. Lerner. Wiley.

Bornstein, M. H. (2017). The specificity principle in acculturation science. Perspectives in Psychological Science, 12(1), 3-45. https://doi.org/10.1177/1745691616655997

Bornstein, M. H. (2019). Fostering optimal development and averting detrimental development: Prescriptions, proscriptions, and specificity. Applied Developmental Science, 23(4), 340-345. https://doi.org/10.1080/10888691.2017.1421424

Bornstein, M. H. (Ed.). (2020). Psychological Insights for Understanding COVID-19 and Families, Parents, and Children. Routledge.

Bornstein, M. H., Jervis, P., \& Lerner, R. M. (in press). Enhancing the international study of character strengths: Process, specificity, and application of positive youth development. Journal of Youth Development.

Bronfenbrenner, U. (2005). Making human beings human: Bioecological perspectives on human development. Sage.

Bronfenbrenner, U., \& Morris, P. A. (2006). The bioecological model of human development. In W. Damon \& R. M. Lerner (Eds.) \& R. M. Lerner (Vol. Ed.), Handbook of child psychology: Vol. 1. Theoretical models of human development (6 $6^{\text {th }}$ ed., pp. 793-828). Wiley.

Burrow, A. L., Agans, J. P., \& Rainone, N. (2018). Exploring purpose as a resource for promoting youth program engagement. Journal of Youth Development, 13(4), 164- 178.

Cantor, P., Osher, D., Berg, J., Steyer, L., \& Rose, T. (2019). Malleability, plasticity, and individuality: How children learn and develop in context. Applied Developmental Science, 23(4), 307-337. 
Journal of Youth Development ｜ http://jyd.pitt.edu/ | Vol. 15 Issue 6 DOI 10.5195/jyd.2020.1056

\section{A Roadmap for Youth Thriving}

Chen, H. T. (2004). Practical program evaluation: Assessing and improving planning, implementation, and effectiveness. Sage.

Damon, W. (2008). The path to purpose: How young people find their calling in life. The Free Press.

Damon, W. (2015). Foreword. In R. M. Lerner (Ed.), Handbook of Child Psychology and Developmental Science ( $7^{\text {th }}$ ed., pp. vii-xiii). Wiley.

Darling-Hammond, L., Flook, L., Cook-Harvey, C., Barron, B., \& Osher, D. (2020). Implications for educational practice of the science of learning and development. Applied Developmental Science, 24(2), 97-140. https://doi.org/10.1080/10888691.2018.1537791

Elder, G. H. (1974). Children of the Great Depression. University of Chicago Press.

Ettekal, A. V., \& Agans, J. P. (2020). Positive youth development through leisure: Confronting the COVID19 pandemic. Journal of Youth Development, 15, 1-20. https://doi.org/10.5195/jyd.2020.962

Fischer, K. W., \& Bidell, T. R. (2006). Dynamic development of action and thought. In R. M. Lerner (Ed.). Theoretical models of human development. Volume 1 of Handbook of Child Psychology (6 $6^{\text {th }} \mathrm{ed}$.) (pp. 313-399). Editors-in-chief: W. Damon \& R. M. Lerner. Wiley.

Kimble, G. A. (1961). Hilgard and Marquis' conditioning and learning. Appleton-Century-Crofts.

Lerner, R. M. (2019). Frontiers in theory-predicated research in youth development: A commentary. Journal of Youth Development, 14(1), 1-23. https://doi.org/10.5195/jyd.2019.739

Lerner, R. M., Lerner, J. V., Bowers, E., \& Geldhof, G. J. (2015) Positive youth development and relational developmental systems. In W. F. Overton \& P. C. Molenaar (Eds.), Theory and method. Volume 1 of the Handbook of child psychology and developmental science ( $7^{\text {th }}$ ed.). Editor-in-chief: R. M. Lerner. (pp. 607-651). Wiley.

Lerner, R. M., Geldhof, G. J., Bowers, E. P. (2019). The science of learning and development: Entering a new frontier of human development theory, research, and application. Applied Developmental Science, 23(4), 305-306. https://doi.org/10.1080/10888691.2019.1630995

Mascolo, M. F., \& Bidell, T. T. (Eds.). (2020). Handbook of Integrative Developmental Psychology: Festschrift for Kurt W. Fischer. Routledge.

Mascolo, M. F., \& Fischer, K. W. (2015) Dynamic Development of Thinking, Feeling, and Acting. In W. F. Overton \& P. C. Molenaar (Eds.), Theory and Method. Volume 1 of the Handbook of Child Psychology and Developmental Science (7 $7^{\text {th }}$ ed.). Editor-in-chief: R. M. Lerner. (pp. 113-161). Wiley.

McClelland, M.M., Geldhof, G. J., Cameron, C. E., \& Wanless, S. B. (2015). Development and selfregulation. In W.F. Overton \& P.C. Molenaar (Eds.), Handbook of child psychology and developmental science. Volume 1: Theory and method ( $7^{\text {th }}$ ed., pp. 523-565). Editor-in-chief: R. M. Lerner. Wiley. 


\section{A Roadmap for Youth Thriving}

McClelland,M., Geldhof, J., Morrison, F., Gestsdóttir, S., Cameron, C., Bowers, E., Duckworth, A., Little, T., \& Grammer, J. et al., 2018 Self-Regulation. In N. Halfon, C. Forrest, R. M. Lerner, \& E. Faustman (Eds.), The Handbook of Life Course Health Development Science (pp. 275-298). Springer.

Osher, D., Cantor, P., Berg, J., Steyer, L., \& Rose, T. (2020). Drivers of human development: How relationships and context shape learning and development. Applied Developmental Science, 24(1), 6-36. https://doi.org/10.1080/10888691.2017.1398650

Overton, W. F. (2015). Process and relational developmental systems. In W. F. Overton \& P. C. M. Molenaar (Eds.), Handbook of Child Psychology and Developmental Science, Volume 1: Theory and Method (7 $7^{\text {th }}$ ed., pp. 9-62). Editor-in-chief: R. M. Lerner. Wiley.

Pawson, R. (2013). The science of evaluation: A realist manifesto. Sage.

Reese, H. W., \& Lipsitt, L. P. (Eds.). (1970). Experimental child psychology. Academic Press.

Rose, T. (2016). The end of average: How we succeed in a world that values sameness. HarperCollins Publishers.

Roth, J. L., \& Brooks-Gunn, J. (2016). Evaluating youth development programs: Progress and promise. Applied Developmental Science, 20(3), 188-202. https://doi.org/10.1080/10888691.2015.1113879

Shonkoff, J. P., Center on the Developing Child (2017). Building a system for science-based R\&D that achieves breakthrough outcomes at scale for young children facing adversity. Center on the Developing Child, Harvard University.

Spencer, M. B. (2006). Phenomenological variant of ecological systems theory (PVEST): A human development synthesis applicable to diverse individuals and groups. In W. Damon \& R. M. Lerner (Eds.) \& R. M. Lerner (Vol. Ed.), Handbook of child psychology: Vol. 6. Theoretical models of human development (6 $6^{\text {th }}$ ed., pp. 829-894). Wiley.

Spencer, M. B., \& Spencer, T. R. (2014). Exploring the promises, intricacies, and challenges to positive youth development. Journal of Youth and Adolescence, 43, 1027-1035.

\section{https://doi.org/10.1007/s10964-014-0125-8}

Spencer, M. B., Swanson, D. P., \& Harpalani, V. (2015). Development of the self. In M. E. Lamb (Volume Ed.), Handbook of child psychology and developmental science, Volume 3: Socioemotional processes (7 $7^{\text {th }}$ ed., pp. 750-793). Editor-in-Chief: R. M. Lerner. Wiley.

Stafford-Brizard, K. B. (2016). Building blocks for learning: A framework for comprehensive student development. Turnaround for Children.

Vandell, D. L., Larson, R. W., Mahoney, J. L., \& Watts, T. W. (2015). Children's organized activities. In M. H. Bornstein \& T. Leventhal (Volume Eds.), Handbook of child psychology and developmental 
Journal of Youth Development | http://jyd.pitt.edu/ | Vol. 15 Issue 6 DOI 10.5195/jyd.2020.1056

\section{A Roadmap for Youth Thriving}

science, Volume 4: Ecological settings and processes (7th ed., pp. 305-344). Editor-in-Chief: R. M. Lerner. Wiley.

Yu, D., Yang, P-J., Geldhof, G. J., Tyler, C., Gansert, P. K. Chase, P. A., \& Lerner, R. M. (2020). Exploring idiographic approaches to children's executive function performance: An intensive longitudinal study. Person-Oriented Research.

Yu, D., Yang, P-J., Michaelson, L. E., Chase, P. A., Gansert, P. K., Osher, D., Berg, J., Tyler, C., Goncalves, C., Park., Y., Boyd-Brown, M. J., Cade, W., Theokas, C., Cantor, P.,\& Lerner, R. M. (Under Review). Enhancing understanding of child development through use of the Bornstein specificity principle: A sample case of executive functioning. Journal of Applied Developmental Psychology. 